\title{
Bisphenolate iron(II) complexes with intramolecularly coordinating nitrogen Lewis bases
}

\author{
Jim A.M. Brandts a, Maurits D. Janssen a , Marinus P. Hogerheide a, Jaap Boersma ${ }^{\text {a }}$, \\ Anthony L. Spek ${ }^{\mathrm{b}, 1}$, Gerard van Koten ${ }^{\mathrm{a}, *}$ \\ a Debye Institute, Department of Metal-Mediated Synthesis, Utrecht University, Padualaan 8, NL-3584 CH Utrecht, The Netherlands \\ ${ }^{\mathrm{b}}$ Bijvoet Institute for Biomolecular Research, Department of Crystal and Structural Chemistry, Utrecht University, Padualaan 8, \\ NL-3584 CH Utrecht, The Netherlands
}

Received 28 December 1998; accepted 29 March 1999

\begin{abstract}
The synthesis and characterisation of a novel $\mathrm{Fe}(\mathrm{II})$ bisphenolate complex $\left[\mathrm{Fe}\left(\mathrm{OC}_{6} \mathrm{H}_{4} \mathrm{CH}_{2} \mathrm{NMe}_{2}-2\right)_{2}\right]_{2}$ (1) from $\left[\mathrm{Na}\left(\mathrm{OC}_{6} \mathrm{H}_{4} \mathrm{CH}_{2} \mathrm{NMe}_{2}-2\right)\right]$ and anhydrous $\mathrm{FeCl}_{2}$ is reported. The solid state structure has been elucidated by single crystal X-ray analysis and shows a dimeric structure with two bridging and two terminal phenolate ligands. Compound 1 reacts with pyridine to form the adduct $\left[\mathrm{Fe}\left(\mathrm{OC}_{6} \mathrm{H}_{4} \mathrm{CH}_{2} \mathrm{NMe}_{2}-2\right)_{2}(\mathrm{py})_{2}\right]$ (2). Similarly, 2 equiv. of $\left[\mathrm{Na}\left(\mathrm{OC}_{6} \mathrm{H}_{2}\left(\mathrm{CH}_{2} \mathrm{NMe}_{2}\right)_{2}-2,6-\mathrm{Me}-4\right)\right]$ were reacted with $\mathrm{FeCl}_{2}$ and the thus in situ prepared ' $\left[\mathrm{Fe}\left(\mathrm{OC}_{6} \mathrm{H}_{2}\left(\mathrm{CH}_{2} \mathrm{NMe}_{2}\right)_{2}-2,6-\mathrm{Me}-4\right)_{2}\right]_{n}$ ' (3) was reacted with pyridine to form the adduct $\left[\mathrm{Fe}\left(\mathrm{OC}_{6} \mathrm{H}_{2}\left(\mathrm{CH}_{2} \mathrm{NMe}_{2}\right)_{2}-2,6-\mathrm{Me}-4\right)_{2}(\mathrm{pyr})_{2}\right]$ (4). Compound 4 was characterised by single crystal X-ray analysis. Attempts to use these compounds as catalysts in the oxidation of cyclohexane with t-butylhydroperoxide (cat:: $\left.\mathrm{C}_{6} \mathrm{H}_{12}: \mathrm{t}-\mathrm{BuOOH}=1: 1000: 100\right)$ resulted in the direct formation of brown coloured products, probably as a result of irreversible oxidation of 1, 2, 3 and 4, respectively. No cyclohexanol or cyclohexanone was formed. (C) 1999 Elsevier Science S.A. All rights reserved.
\end{abstract}

Keywords: Crystal structures; Iron complexes; Phenolate complexes

\section{Introduction}

The synthesis and characterisation of mono- and binuclear iron complexes has been the subject of many articles published in the literature because they play an important role in selective catalystic oxidation reactions in nature [1,2]. Mononuclear complexes have been reported by Que and co-workers [3], Nashida and Yamada [4] and Tachibana et al. [5]. Catalytic oxidation activity using iron-oxygen complexes and an oxygen source like $\mathrm{O}_{2}, \mathrm{H}_{2} \mathrm{O}_{2}$ or t-butylhydroperoxide was reported by different groups, although turnover numbers do not generally exceed 100 per hour [6-8]. The most active compound reported by Que and co-workers [3] contains an $\mathrm{Fe}(\mathrm{III})$ unit, two phenolate ligands and

\footnotetext{
* Corresponding author. Tel.: + 31-30-253 1889/3120; fax: + 3130-252 3615.

E-mail address: g.vankoten@chem.uu.nl (G. van Koten)

${ }^{1}$ Address correspondence pertaining to crystallographic studies to this author; e-mail: A.L.Spek@chem.uu.nl
}

four neutral nitrogen donor ligands. The presence of at least one free coordination site at one of the iron ions and stabilisation of different oxidation states of the iron ions appeared to be a prerequisite for the observation of any significant catalytic activity [9].

In order to develop new mononuclear and binuclear iron complexes that possess such properties, it is necessary to choose ligands that can stabilise higher oxidation states of the metal centre, create an open coordination site at the same time and can serve as a bridging moiety between two different iron nuclei.

Monoanionic bi- and tri-dentate phenolate ligands containing one or more potentially tertiary $\mathrm{N}$-donor substituents are able to compromise these conditions. In order to accommodate the iron-group metals with high oxidation numbers, we have chosen the ligands in Fig. 1, which contain potentially intramolecularly coordinating tertiary trialkyl amino substituents.

These ligand systems can stabilise the metal centre through coordination of the donor substituents. The 


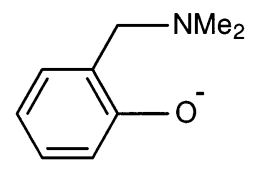

(a)

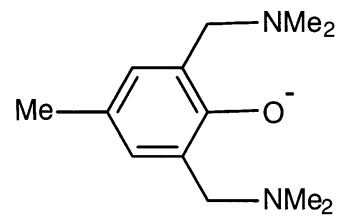

(b)
Fig. 1. Selected monoanionic, ortho mono- and bis-chelating phenoxy ligands.

phenolate ligand $\mathrm{B}$ has been found to be especially suitable for the coordination of two or more metal atoms, which is of importance for the preparation of a single bimetallic complex. Examples of sodium, aluminium and yttrium or mixed sodium/yttrium and sodium/lutetium complexes have been reported by our group [10] and manganese [11], copper [12,13], iron [14], lithium [15], barium [16] and potassium [16] complexes of similar phenolate ligands by others.

Here we report on the synthesis, reactivity and structural aspects of the new iron(II) phenolate complexes $\left[\mathrm{Fe}\left(\mathrm{OC}_{6} \mathrm{H}_{4} \mathrm{CH}_{2} \mathrm{NMe}_{2}-2\right)_{2}\right]_{2} \quad$ (1), $\left[\mathrm{Fe}\left(\mathrm{OC}_{6} \mathrm{H}_{4} \mathrm{CH}_{2} \mathrm{NMe}_{2}-\right.\right.$ $\left.2)_{2}(\text { py })_{2}\right](2)$, in situ prepared ' $\left[\mathrm{Fe}\left(\mathrm{OC}_{6} \mathrm{H}_{2}\left(\mathrm{CH}_{2} \mathrm{NMe}_{2}\right)_{2}\right.\right.$ $\left.2,6-\mathrm{Me}-4)_{2}\right]_{n}{ }^{\prime}(3)$ and $\left[\mathrm{Fe}\left(\mathrm{OC}_{6} \mathrm{H}_{2}\left(\mathrm{CH}_{2} \mathrm{NMe}_{2}\right)_{2}-2,6-\mathrm{Me}-\right.\right.$ $\left.4)_{2}(\mathrm{py})_{2}\right]$ (4).

\section{Results}

Reaction of 2 equiv. of the sodium phenolate [ $\mathrm{Na}\left(\mathrm{OC}_{6} \mathrm{H}_{4} \mathrm{CH}_{2} \mathrm{NMe}_{2}\right.$-2)] [17] with anhydrous iron(II) chloride in $\mathrm{Et}_{2} \mathrm{O}$ at ambient temperature affords, in virtually quantitative yield, the iron(II) bisphenolate complex $\left[\mathrm{Fe}\left(\mathrm{OC}_{6} \mathrm{H}_{4} \mathrm{CH}_{2} \mathrm{NMe}_{2}-2\right)_{2}\right]_{2}$ (1) (see Scheme 1).

Complex $\mathbf{1}$ is an off-white coloured solid which turns brown within $5 \mathrm{~min}$ upon exposure to air. The iron phenolate $\mathbf{1}$ is soluble in most polar and non-polar organic solvents and is thermally stable as a solid up to $200^{\circ} \mathrm{C}$. The ${ }^{1} \mathrm{H}$ NMR spectrum of the compound in THF- $\mathrm{d}_{8}$ shows both sharp and broad signals that span $75 \mathrm{ppm}$. These data are indicative of a high spin Fe(II) complex in which the two iron centres are probably antiferromagnetically coupled [18]. Upon exposure to air these signals tend to sharpen and ultimately span a spectral width from 26 to $-1 \mathrm{ppm}$. However, neither a solution of the iron(II) compound $\mathbf{1}$ nor the brown products obtained after reaction with air show EPR signals at room temperature (r.t.). Cooling of the solid in liquid nitrogen did not change the colour of $\mathbf{1}$ indicating that temperature-dependent electron redistribution does not take place. To elucidate the geometry of this iron compound and prove the intramolecular nitrogen coordination an X-ray structure determination was carried out.

Yellowish crystals suitable for X-ray analysis were obtained by slow distillation of pentane into a THF
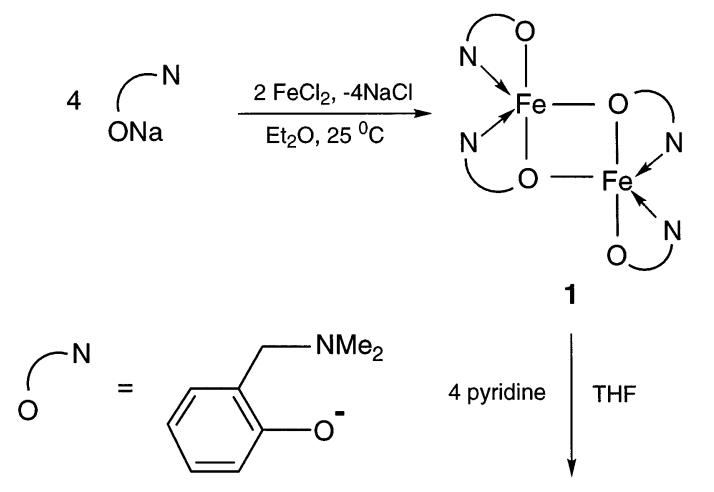

2

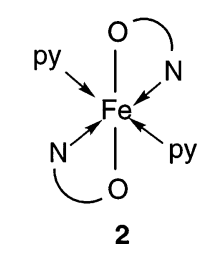

Scheme 1. Synthesis of $\left[\mathrm{Fe}\left(\mathrm{OC}_{6} \mathrm{H}_{4} \mathrm{CH}_{2} \mathrm{NMe}_{2}-2\right)_{2}\right]_{2}$ (1) and the pyridine adduct $\left[\mathrm{Fe}\left(\mathrm{OC}_{6} \mathrm{H}_{4} \mathrm{CH}_{2} \mathrm{NMe}_{2}-2\right)_{2}(\mathrm{py})_{2}\right]$ (2).

solution of $\mathbf{1}$ at $-20^{\circ} \mathrm{C}$. The molecular structure of $\mathbf{1}$, with the adopted numbering scheme, is depicted in Fig. 2. Table 1 shows some important distances and angles in the molecule.

In the solid state $\mathbf{1}$ is a dimeric iron(II) species with an inversion point positioned at the crossing of the virtual lines Fe1-Fela and O1-O1a. The compound contains two bridging and two terminal phenoxide groups. The $\mathrm{Fe}_{2} \mathrm{O}_{4}$ core is essentially planar. The nitrogens of both a bridging and a terminal ligand are coordinated to each of the two iron ions. The iron ions are penta-coordinated in a square pyramidal fashion ( $82.5 \%$ along the Berry pseudorotation coordinate from trigonal-bipyramidal to square-pyramidal geometry) with the terminal oxygens at the apical positions. Bartlett et al. [14] have found a similar solid state structure for $\left[\mathrm{Fe}\left(\mathrm{OC}_{6} \mathrm{H}_{2}-2,4,6-\mathrm{t}-\mathrm{Bu}_{3}\right)_{2}\right]_{2}$.

Reaction of $\mathbf{1}$ with pyridine affords the pyridine adduct 2 (see Scheme 2). Upon addition of the pyridine the colour immediately changes from yellow to dark red. After removal of the solvents a red solid was obtained of which the ${ }^{1} \mathrm{H}$ NMR spectrum spans a range of $100 \mathrm{ppm}$ at r.t. in $\mathrm{C}_{6} \mathrm{D}_{6}$. The broad and sharp resonances with chemical shifts between 85 and -25 ppm are characteristic of a high-spin Fe(II) compound [18]. No EPR resonances were found at r.t. The mass balance and elemental analysis were in agreement with the general formula $\left[\mathrm{Fe}\left(\mathrm{OC}_{6} \mathrm{H}_{4} \mathrm{CH}_{2} \mathrm{NMe}_{2}-2\right)_{2}(\mathrm{py})_{2}\right]$ (2). The red solid also turned brown upon exposure to air, but this product is less reactive towards air compared to 1 .

When 2 equiv. of $\mathrm{Na}\left(\mathrm{OC}_{6} \mathrm{H}_{2}\left(\mathrm{CH}_{2} \mathrm{NMe}_{2}\right)_{2}-2,6-\mathrm{Me}-4\right)$ [17] were reacted with $\mathrm{FeCl}_{2}$ at ambient temperature and subsequent removal of the $\mathrm{NaCl}$ formed, a mixture 


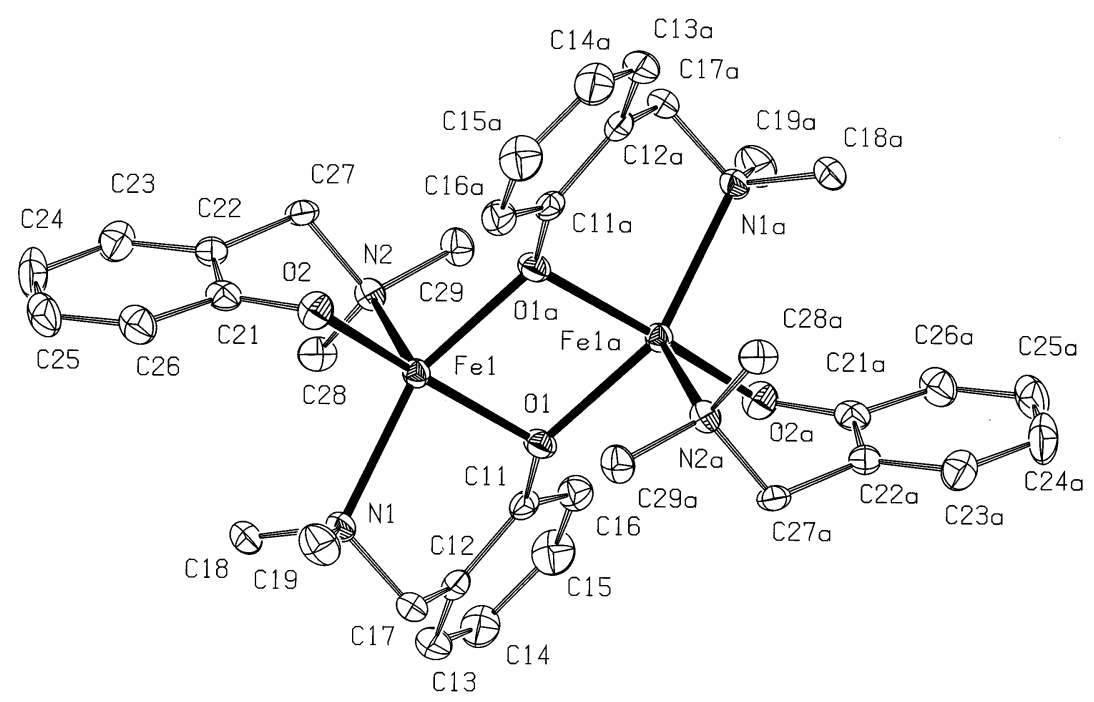

Fig. 2. ORTEP drawing (50\% probability atomic displacement ellipsoids) of 1. Hydrogen atoms have been omitted for clarity.

of a very air-sensitive white solid and a brown oil was obtained. Attempts to purify both species were unsuccessful because of the high solubility of the brown oil and the air sensitivity of both the oil and the white solid. The mixture showed broad ${ }^{1} \mathrm{H}$ NMR signals in the range of 37-0 ppm spectral width. Upon exposure to air, the NMR spectrum changed (new resonances showed between 28 and $0 \mathrm{ppm}$ ) indicating the formation of new compounds, which did not show EPR signals at r.t. When the earlier mentioned mixture of the very air-sensitive white solid and the brown oil were reacted with an excess of pyridine again a red compound was obtained in high yield; the mass balance of the reaction indicated that the pyridine adduct

Table 1

Selected geometrical details of $\mathbf{1}^{\text {a }}$ and $\mathbf{4}^{\text {a }}$

\begin{tabular}{|c|c|c|c|}
\hline 1 & & 4 & \\
\hline \multicolumn{4}{|l|}{ Bond lengths (§) } \\
\hline Fel-Fela & $3.2602(15)$ & $\mathrm{Fel}-\mathrm{O} 1$ & $1.983(2)$ \\
\hline Fe1-O1 bridge & $2.152(3)$ & Fe1-N1 & $2.354(3)$ \\
\hline $\mathrm{Fe} 1-\mathrm{O} 2$ terminal & $1.942(3)$ & $\mathrm{Fe} 1-\mathrm{N} 3$ & $2.273(2)$ \\
\hline Fe1-Ola bridge & $2.024(3)$ & $\mathrm{O} 1-\mathrm{C} 1$ & $1.328(3)$ \\
\hline $\mathrm{Fe} 1-\mathrm{N} 2$ & $2.227(5)$ & & \\
\hline $\mathrm{Fe} 1-\mathrm{N} 1$ & $2.289(3)$ & & \\
\hline $\mathrm{O} 1-\mathrm{C} 11$ & $1.351(5)$ & & \\
\hline $\mathrm{O} 2-\mathrm{C} 21$ & $1.350(6)$ & & \\
\hline \multicolumn{4}{|l|}{ Bond angles $\left({ }^{\circ}\right)$} \\
\hline Fe1-O1-Fela & $102.61(13)$ & $\mathrm{O} 1-\mathrm{Fe} 1-\mathrm{O} 1 \mathrm{a}$ & $180.0(4)$ \\
\hline O1-Fe1-O1a & $77.39(12)$ & $\mathrm{N} 1-\mathrm{Fe}-\mathrm{N} 3$ & $89.79(9)$ \\
\hline Fela-O1-C11 & $131.2(3)$ & $\mathrm{Fe} 1-\mathrm{O} 1-\mathrm{C} 1$ & $132.48(16)$ \\
\hline $\mathrm{Fe} 1-\mathrm{O} 2-\mathrm{C} 21$ & $117.8(3)$ & $\mathrm{N} 3-\mathrm{Fe}-\mathrm{N} 3 \mathrm{a}$ & $180.0(8)$ \\
\hline $\mathrm{O} 1-\mathrm{Fe} 1-\mathrm{O} 2$ & $164.95(16)$ & & \\
\hline $\mathrm{N} 1-\mathrm{Fe} 1-\mathrm{N} 2$ & $111.37(15)$ & & \\
\hline
\end{tabular}

\footnotetext{
a The estimated standard deviations of the last significant digits are shown in parentheses.
}

$\left[\mathrm{Fe}\left(\mathrm{OC}_{6} \mathrm{H}_{2}\left(\mathrm{CH}_{2} \mathrm{NMe}_{2}\right)_{2}-2,6-\mathrm{Me}-4\right)_{2}(\mathrm{pyr})_{2}\right]$ (4) had been formed (see Scheme 2).

Cooling the solid in liquid nitrogen did not change the colour of $\mathbf{4}$ which shows that again electron redistribution does not take place. To elucidate the geometry of this iron compound, an X-ray structure determination was carried out. Red crystals suitable for X-ray analysis were obtained by cooling a saturated ether solution of $\mathbf{4}$ to $-20^{\circ} \mathrm{C}$. The molecular structure of $\mathbf{4}$, with the adopted numbering scheme, is depicted in Fig. 3. Table 1 shows some important distances and angles in the molecule.

The single crystal X-ray structure determination showed 4 to contain one iron(II) centre bound to two phenoxide ligands and two pyridine ligands. The structure has an inversion point positioned at the iron centre. The iron atom is almost perfectly octahedrally surrounded by the two monoanionic, bidentate $\left[\mathrm{OC}_{6} \mathrm{H}_{2}\left(\mathrm{CH}_{2} \mathrm{NMe}_{2}\right)_{2}-2,6-\mathrm{Me}-4\right]^{-}$ligands and two pyridines. Each of the two phenolate ligands uses one of its ortho-amino substituents to coordinate to the iron atom, while the second ortho-amino substituent is pendant. The ${ }^{1} \mathrm{H}$ NMR spectrum of $\mathbf{4}$ showed broad peaks spanning a spectral width from 37 to $0 \mathrm{ppm}$ in $\mathrm{C}_{6} \mathrm{D}_{6}$, characteristic of a high-spin iron(II) compound [18]. Upon exposure to air $\mathbf{4}$ quickly changes colour from red to brown, both in solution and in the solid state. Both compound $\mathbf{4}$ and the brown products obtained after reaction with air are EPR silent.

Attempts to use the new $\mathrm{Fe}(\mathrm{II})$ bisphenolate complexes as catalysts in the oxidation of cyclohexane, with t-butylhydroperoxide as the oxygen source, were unsuccessful (molar ratio catalyst:substrate:oxidant = 1:1000:100). Immediately after addition of the hydroperoxide solution the colour of the reaction mixtures changed to brown. Attempts to isolate and characterise the brown soluble oils that had formed were 

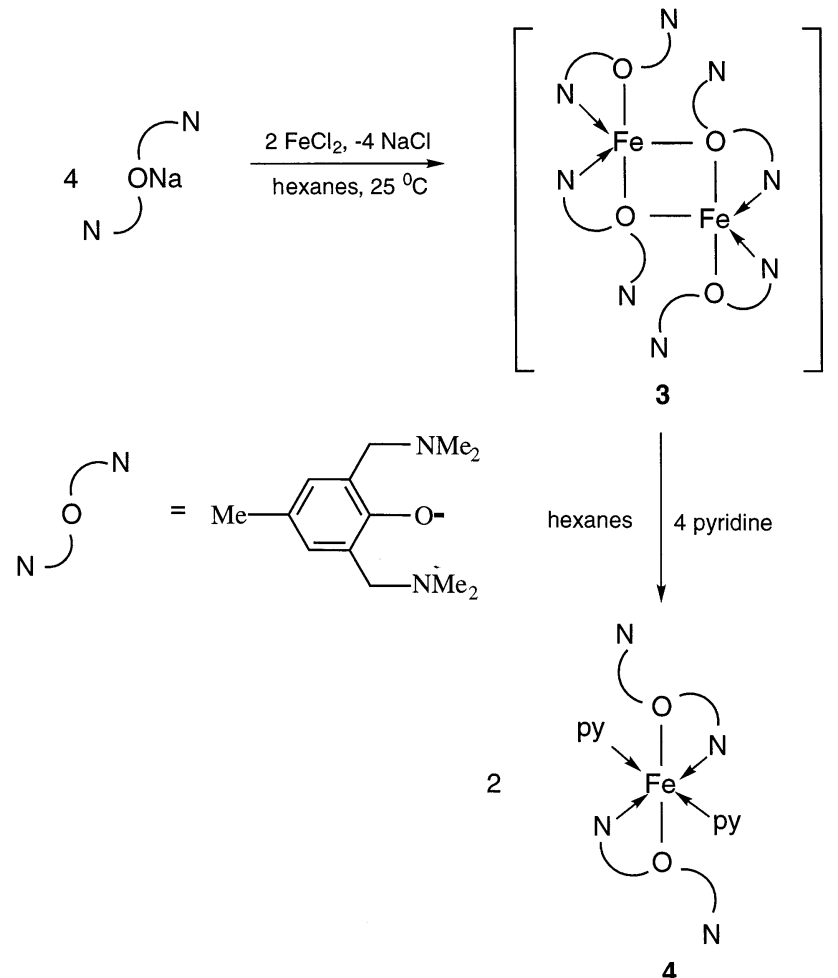

Scheme 2. Synthesis of the pyridine adduct $\left[\mathrm{Fe}\left(\mathrm{OC}_{6} \mathrm{H}_{2}\left(\mathrm{CH}_{2} \mathrm{NMe}_{2}\right)_{2}-\right.\right.$ 2,6-Me-4) $\left.)_{2}(\mathrm{pyr})_{2}\right](\mathbf{4})$.

unsuccessful. No oxidation products like cyclohexanol or cyclohexanone were found.

\section{Discussion}

The fact that no EPR signals were found for the iron compounds 1 and 2, in situ prepared ' $\left[\mathrm{Fe}\left(\mathrm{OC}_{6} \mathrm{H}_{2}\right.\right.$ $\left.\left.\left(\mathrm{CH}_{2} \mathrm{NMe}_{2}\right)_{2}-2,6-\mathrm{Me}-4\right)_{2}\right]_{n}{ }^{\prime}$ (3) and 4 and the brown products obtained after reaction with air at r.t. indicates that either the compounds are EPR silent or the resonances are too broad to be observed. The NMR spectra of compounds $\mathbf{1}$ and $\mathbf{2}$, in situ prepared $\mathbf{3}$ and $\mathbf{4}$ have characteristic patterns but cannot be used to characterise the compounds structurally.

Compound 3 could not be isolated as a pure compound. Attempts to characterise the products of its formation reaction always showed a mixture of starting compounds and high-spin iron(II) species. Although we were unable to isolate or structurally characterise $\mathbf{3}$, we presume that a dimeric iron(II) complex with a non-coordinating second dimethylamino ortho-substituent, similar to $\mathbf{1}$, is formed during the initial reaction of the sodium phenolate and $\mathrm{FeCl}_{2}$. The almost quantitative formation of $\mathrm{NaCl}$ could be detected. Moreover, addition of pyridine gave its pyridine adduct $\mathbf{4}$ in a high yield.

The terminal phenolate ligands in the solid state structures of $\mathbf{1}$ and $\mathbf{4}$ show different bond distances and bond angles. The $\mathrm{Fe}-\mathrm{O}$ and $\mathrm{Fe}-\mathrm{N}$ distances for compound 1 are shorter $(\mathrm{Fe} 1-\mathrm{O} 2=1.942(3)$ and $\mathrm{Fe} 1-$ $\mathrm{N} 2=2.227(5) \AA)$ than those in $4(\mathrm{Fe} 1-\mathrm{O} 1=1.983(2)$ and $\mathrm{Fe} 1-\mathrm{N} 1=2.354(3) \AA$ ). In contrast the $\mathrm{O} 2-\mathrm{C} 21$ distance in $\mathbf{1}$ is longer $(1.350(6) \AA$ ) than this distance in $4(\mathrm{O} 1-\mathrm{C} 1=1.328(3) \AA)$. The angle between $\mathrm{Fe} 1, \mathrm{O} 2$ and $\mathrm{C} 21$ in $\mathbf{1}\left(117.8(3)^{\circ}\right)$ is much smaller compared to the same angle in compound $4\left(132.48(16)^{\circ}\right)$.

Compound 1 is more asymmetric than the similar iron phenolate $\left[\mathrm{Fe}\left(\mathrm{OC}_{6} \mathrm{H}_{2}-2,4,6-\mathrm{t}-\mathrm{Bu}_{3}\right)_{2}\right]_{2}$ reported by Bartlett [14]. This is a result of (i) the presence of two coordinating amino substituents in $\mathbf{1}$, which reduces the Lewis acidity of the metal centre, and (ii) the formation of the six-membered chelate rings, which pull the ligand over, leading to relatively small $\mathrm{Fe}-\mathrm{O}-\mathrm{C}$ bond angles and reduce the s-character in the $\mathrm{Fe}-\mathrm{O}$ bond.

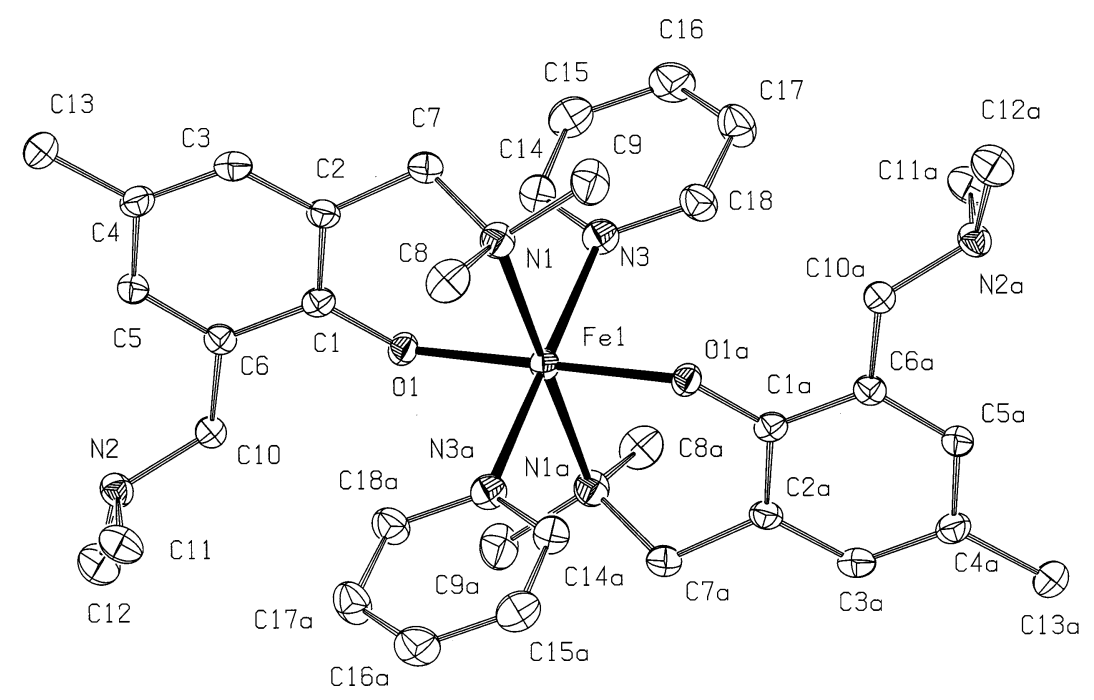

Fig. 3. ORTEP drawing (50\% probability atomic displacement ellipsoids) of 4 . Hydrogen atoms have been omitted for clarity. 


\section{Conclusion}

We have synthesised new iron(II) bisphenolate complexes and their corresponding pyridine adducts. The monoanionic bi- and tridentate phenolate ligands containing potentially amine $\mathrm{N}$ donor substituents can stabilise both mono- and binuclear $\mathrm{Fe}$ (II) compounds. They all showed broad signals in ${ }^{1} \mathrm{H}$ NMR spectra characteristic of high spin Fe(II) complexes. No EPR signals were observed at r.t. All compounds were sensitive towards air and other dioxygen sources and were rapidly oxidised to brown oils or solids. No catalytic activity was found in test reactions of cyclohexane with air or t-butylhydroperoxide due to irreversible oxidation of the complexes.

\section{Experimental}

\subsection{General}

Syntheses were carried out using standard Schlenk techniques under an atmosphere of dry, oxygen-free nitrogen. Toluene, benzene, hexane, and pentane were carefully dried and distilled from sodium benzophenone-ketyl prior to use. $\mathrm{CH}_{2} \mathrm{Cl}_{2}$ was distilled from $\mathrm{CaH}_{2}$. Pyridine was dried on molecular sieves $(4 \AA)$ and distilled prior to use. UV-Vis were recorded on a Cary 1 using spectroscopic grade $\mathrm{CH}_{2} \mathrm{Cl}_{2}$ and benzene. NMR spectra $\left({ }^{1} \mathrm{H}\right.$ and $\left.{ }^{13} \mathrm{C}\left\{{ }^{1} \mathrm{H}\right\}\right)$ were recorded on Bruker AC200 and Bruker AC300 spectrometers, with chemical shifts referenced to $\mathrm{Me}_{4} \mathrm{Si}$. EPR spectra were recorded on a Varian E-4 EPR spectrometer at r.t. in the X-band at $9.26 \mathrm{GHz}$. Elemental analyses were carried out by Dornis und Kolbe, Mikroanalytisches Laboratorium, Mülheim a.d. Ruhr, Germany. The compounds 2-[(dimethylamino)methyl] phenol [17], 2,6bis[(dimethylamino)methyl]-4-methylphenol [17], and the corresponding sodium phenolates [17] were prepared according to literature procedures. Anhydrous iron(II) chloride was obtained by reaction of iron powder with gaseous $\mathrm{HCl}$ in THF [19].

\section{2. $\left[\mathrm{Fe}\left(\mathrm{OC}_{6} \mathrm{H}_{4} \mathrm{CH}_{2} \mathrm{NMe}_{2}-2\right)_{2}\right]_{2}$ (1)}

To a solution of $\left[\mathrm{Na}\left(\mathrm{OC}_{6} \mathrm{H}_{4} \mathrm{CH}_{2} \mathrm{NMe}_{2}-2\right)\right](1.73 \mathrm{~g}$, $10.0 \mathrm{mmol})$ in $\mathrm{Et}_{2} \mathrm{O}(100 \mathrm{ml})$ was added anhydrous $\mathrm{FeCl}_{2}(0.64 \mathrm{~g}, 5.0 \mathrm{mmol})$ as a solid at ambient temperature. After stirring for $2.5 \mathrm{~h}$, a white solid was collected by centrifugation and subsequent removal of the mother liquor. The white precipitate was extracted with THF $(3 \times 30 \mathrm{ml})$, the precipitate was removed by centrifugation and the slightly coloured THF layers were combined. All volatiles were removed in vacuo. Washing of the solid residue with pentane $(3 \times 15 \mathrm{ml})$ and drying in vacuo afforded $\mathbf{1}$ in an $89 \%$ yield $(1.60 \mathrm{~g})$ as a cream-coloured solid. M.p. $>205^{\circ} \mathrm{C}$. UV-Vis $\left(\mathrm{CH}_{2} \mathrm{Cl}_{2}\right): \lambda_{\max }(\lg \varepsilon)=370 \mathrm{~nm}$ (3.17), 275 (3.96), 228 (4.16). ${ }^{1} \mathrm{H}$ NMR $\left(\mathrm{THF}-\mathrm{d}_{8}, 200 \mathrm{MHz}, 297 \mathrm{~K}\right) \delta(\mathrm{ppm})$ : - 18.9, - 15.5, 21.0, 22.1, 28.0, 32.6, 49.5. Anal. Calc. for $\mathrm{C}_{18} \mathrm{H}_{24} \mathrm{FeN}_{2} \mathrm{O}_{2}$ : C, 60.69; $\mathrm{H}, 6.79 ; \mathrm{N}, 7.86$. Found: $\mathrm{C}, 59.61 ; \mathrm{H}, 6.72 ; \mathrm{N}, 7.75 \%$. The elemental analysis showed a low percentage in carbon. Because of its high sensitiveness towards air it is possible that a percentage had already reacted with dioxygen. Calculations of stoichiometries in which 0.5 equiv. of dioxygen is incorporated in the bruto formula give better fitting. Crystals suitable for an X-ray structure determination were obtained by slow diffusion of pentane into a THF solution of 1 at $-20^{\circ} \mathrm{C}$.

\section{3. $\left[\mathrm{Fe}\left(\mathrm{OC}_{6} \mathrm{H}_{4} \mathrm{CH}_{2} \mathrm{NMe}_{2}-2\right)_{2}(\mathrm{py})_{2}\right]$ (2)}

To a suspension of $1(0.79 \mathrm{~g}, 1.11 \mathrm{mmol})$ in THF (60 $\mathrm{ml})$ was added dry deoxygenated pyridine $(0.8 \mathrm{ml}, 9.9$ $\mathrm{mmol})$. The colour changed immediately from yellow to deep red. After $2 \mathrm{~h}$ the volatiles were evaporated in vacuo. The red solid was washed three times with pentane. The product (yield $74 \%$ ) was characterised by ${ }^{1} \mathrm{H}$ NMR, UV-Vis and elemental analysis. M.p. 135$137^{\circ} \mathrm{C}$. UV-Vis (benzene): $\lambda_{\max }(\lg \varepsilon)=375 \mathrm{~nm}(3.63)$, 318 (3.83), 281 (4.09). ${ }^{1} \mathrm{H}$ NMR $\left(\mathrm{C}_{6} \mathrm{D}_{6}, 200 \mathrm{MHz}, 297\right.$ K) $\delta(\mathrm{ppm}):-22.0,-6.0,19.7,25.1,28.0,34.4,60.7$. Anal. Calc. for $\mathrm{C}_{28} \mathrm{H}_{34} \mathrm{FeN}_{4} \mathrm{O}_{2}$ : C, 65.37; H, 6.66; N, 10.89. Found: C, 65.26; H, 6.70; N, 10.86\%.

\subsection{In situ prepared \\ ' $\left.\mathrm{Fe}\left(\mathrm{OC}_{6} \mathrm{H}_{2}\left(\mathrm{CH}_{2} \mathrm{NMe}_{2}\right)_{2}-2,6-\mathrm{Me}-4\right)_{2}\right]_{n}$ ' (3)}

To a suspension of $\left[\mathrm{Na}\left(\mathrm{OC}_{6} \mathrm{H}_{2}\left(\mathrm{CH}_{2} \mathrm{NMe}_{2}\right)_{2}-2,6-\mathrm{Me}-\right.\right.$ 4)] $(1.12 \mathrm{~g}, 4.58 \mathrm{mmol})$ in hexane $(100 \mathrm{ml})$ was added anhydrous $\mathrm{FeCl}_{2}(0.28 \mathrm{~g}, 2.21 \mathrm{mmol})$ at ambient temperature. The reaction mixture was stirred for $3 \mathrm{~h}$ and was used as such. Efforts to isolate 3 included the separation of the precipitate from the slightly brown coloured solution by decantation. The brown solution was concentrated in vacuo to give a brown soluble oil. Efforts to sublime this oil were in vain.

\section{5. $\left[\mathrm{Fe}\left(\mathrm{OC}_{6} \mathrm{H}_{2}\left(\mathrm{CH}_{2} \mathrm{NMe}_{2}\right)_{2}-2,6-\mathrm{Me}-4\right)_{2}(\mathrm{pyr})_{2}\right]$ (4)}

To a solution of $\mathbf{3}$ in hexane $(100 \mathrm{ml})$ was added dry deoxygenated pyridine $(1.0 \mathrm{ml}, 12.4 \mathrm{mmol})$. The colour immediately changed from slightly brown to deep red. The solvent was evaporated and the red solid was dissolved in diethyl ether. The remaining white precipitate was removed and the solvent of the diethyl ether solution was concentrated. The remaining red solid was washed three times with pentane. The product (yield $87 \%$ ) was characterised by ${ }^{1} \mathrm{H}$ NMR, UV-Vis, elemental and X-ray structure analysis. M.p. $152-154^{\circ} \mathrm{C}$. $\mathrm{UV}-\mathrm{Vis}$ (benzene): $\lambda_{\max }(\lg \varepsilon)=389 \mathrm{~nm}$ (3.52), 326 
(3.69), 292 (3.91). ${ }^{1} \mathrm{H}$ NMR $\left(\mathrm{C}_{6} \mathrm{D}_{6}, 200 \mathrm{MHz}, 297 \mathrm{~K}\right) \delta$ (ppm): 18.0, 25.7, 32.2, 36.4. Anal. Calc. for: $\mathrm{C}_{36} \mathrm{H}_{52} \mathrm{Fe}_{1} \mathrm{~N}_{6} \mathrm{O}_{2}: \mathrm{C}, 65.84 ; \mathrm{H}, 7.98 ; \mathrm{N}, 12.80$. Found: $\mathrm{C}$, $66.49 ; \mathrm{H}, 8.06 ; \mathrm{N}, 11.49 \%$. The elemental analysis of compound 4 gives better fitting when 0.5 equiv. of pentane is incorporated in the sample. Pentane was used to extract excess pyridine from the sample. Crystals suitable for an X-ray structure determination were obtained by cooling a saturated diethyl ether solution of 4 to $-20^{\circ} \mathrm{C}$.

\subsection{Structure determination and refinement of $\mathbf{1}$ and $\mathbf{4}$}

X-ray data were collected on an Enraf-Nonius CAD4T rotating anode diffractometer for a transparent, yellowish (1) or red (4) crystal glued on top of a glass fibre. The unit-cell parameters were checked for the presence of higher lattice symmetry. Data were corrected for Lorentz polarisation effects. An empirical absorption correction was applied (PLATON/DELABS) [20]. The structures were solved by Direct methods and subsequent difference Fourier techniques (SHELXs86) [21]. Refinement on $F^{2}$ was carried out by full-matrix least-squares techniques (SHELXL93) [22] using no observance criterion. Hydrogen atoms were included on calculated positions, riding on their carrier atoms. All non-hydrogen atoms were refined with anisotropic atomic displacement parameters. All hydrogen atoms were refined with a fixed isotropic atomic displacement parameter related to the value of the equivalent isotropic atomic displacement parameter of their carrier atom. Weights were optimized in the final refinement cycles. Neutral atom scattering factors and anomalous dispersion corrections were taken from the International Tables for Crystallography [23]. Geometrical calculations and illustrations were performed with PLATON [20]. All calculations were performed on a DECstation 5000 cluster. Crystal data and numerical details of the structure determinations and refinements are collected in Table 2. Selected geometrical details of the structures of $\mathbf{1}$ and $\mathbf{4}$ are listed in Table 1 .

\section{Supplementary material}

Crystallographic data (excluding structure factors) for the structures reported in this paper have been deposited with the Cambridge Crystallographic Data Centre as supplementary publication no. CCDC-102170 (structure 1) and CCDC-102171 (structure 4). Copies of the data can be obtained free of charge on application to CCDC, 12 Union Road, Cambridge CB2 1EZ, UK (Fax: +44-1223-336-033; e-mail: deposit@ccdc. cam.ac.uk).
Table 2

Experimental data for the X-ray diffraction studies of $\mathbf{1}$ and $\mathbf{4}$

\begin{tabular}{|c|c|c|}
\hline & 1 & 4 \\
\hline Formula & $\mathrm{C}_{36} \mathrm{H}_{48} \mathrm{Fe}_{2} \mathrm{~N}_{4} \mathrm{O}_{4}$ & $\mathrm{C}_{36} \mathrm{H}_{52} \mathrm{FeN}_{6} \mathrm{O}_{2}$ \\
\hline Formula weight & 712.50 & 656.69 \\
\hline Temperature (K) & 150 & 150 \\
\hline Crystal system & monoclinic & monoclinic \\
\hline Space group & $C 2 / c$ (no. 15$)$ & $P \overline{1}$ (no. 2) \\
\hline$a(\AA)$ & $24.215(9)$ & $9.0735(5)$ \\
\hline$b(\AA)$ & $9.881(4)$ & $10.1035(5)$ \\
\hline$c(\AA)$ & $16.283(6)$ & $10.1777(6)$ \\
\hline$\alpha\left({ }^{\circ}\right)$ & & $102.029(4)$ \\
\hline$\beta\left({ }^{\circ}\right)$ & $118.76(3)$ & $97.409(5)$ \\
\hline$\gamma\left({ }^{\circ}\right)$ & & $103.387(4)$ \\
\hline Volume $\left(\AA^{3}\right)$ & $3415(2)$ & $872.22(8)$ \\
\hline$Z$ & 4 & 1 \\
\hline$D_{\text {calc }}\left(\mathrm{g} \mathrm{cm}^{-3}\right)$ & 1.386 & 1.250 \\
\hline$F(000)$ (electrons) & 1504 & 352 \\
\hline$\mu(\mathrm{Mo} \mathrm{K} \alpha)\left(\mathrm{cm}^{-1}\right)$ & 8.9 & 4.7 \\
\hline Crystal size $(\mathrm{mm})$ & $0.12 \times 0.50 \times 0.60$ & $0.20 \times 0.25 \times 0.25$ \\
\hline Radiation $(\AA)$ & Mo $\mathrm{K} \alpha(0.71073)^{\text {a }}$ & Mo $K \alpha(0.71073)^{a}$ \\
\hline$\theta_{\min }, \theta_{\max }\left({ }^{\circ}\right)$ & $1.43,25.00$ & $2.1,27.5$ \\
\hline $\operatorname{Scan}(\omega / 2 \theta$-mode $)\left(^{\circ}\right)$ & $1.00+0.35 \tan (\theta)$ & $0.75+0.35 \tan (\theta)$ \\
\hline$h ; k ; l$ (min., max.) & $\begin{array}{l}-10,11 ; 0,15 \\
-17,18\end{array}$ & $\begin{array}{l}-11,11 ;-12,13 \\
-13,0\end{array}$ \\
\hline $\begin{array}{l}\text { Total/unique reflec- } \\
\text { tions }\end{array}$ & 6309,3014 & 4226,4001 \\
\hline Observed reflections & $2295(F>4 \sigma(F))$ & $3062(F>4 \sigma(F))$ \\
\hline$N_{\text {ref }}, N_{\text {par }}$ & 3014,208 & 4001,205 \\
\hline$R, w R, S^{\mathrm{b}}$ & $0.0617,0.1689,1.04$ & $0.0531,0.1364,1.04$ \\
\hline Weight $\left(w^{-1}\right)^{\mathrm{c}}$ & $\sigma^{2}\left(F_{\mathrm{o}}^{2}\right)+(0.0983 P)^{2}$ & $\begin{array}{l}\sigma^{2}\left(F_{\mathrm{o}}^{2}\right)+(0.0726 P)^{2} \\
\quad+0.1137 P\end{array}$ \\
\hline $\begin{array}{l}\text { Min., max. residual } \\
\text { density }\left(\mathrm{e} \AA^{-3}\right)\end{array}$ & $-0.64,0.69$ & $-0.35,0.53$ \\
\hline
\end{tabular}

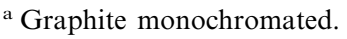

${ }^{\mathrm{b}} R=\Sigma\left\|F_{\mathrm{o}}|-| F_{\mathrm{c}}\right\| / \Sigma\left|F_{\mathrm{o}}\right| \cdot w R_{2}=\left\{\Sigma\left[w\left(F_{\mathrm{o}}^{2}-F_{\mathrm{c}}^{2}\right)^{2}\right] / \Sigma\left[w\left(F_{\mathrm{o}}^{2}\right)^{2}\right]\right\}^{1 / 2}$

${ }^{\mathrm{c}} P=\left(\max \left(F_{\mathrm{o}}^{2}, 0\right)+2 F_{\mathrm{c}}^{2}\right) / 3$.

\section{References}

[1] (a) L. Que, Jr., J. Chem. Ed., 62 (1985) 938. (b) L. Que, Jr., R.Y.N. Ho, Chem. Rev. 96 (1996) 2607. (b) R.E. Stenkamp, Chem. Rev. 94 (1994) 715. (c) M.A. Holmes, I.L. Trong, S. Turley, L.C. Sieker, R.E. Stenkamp, J. Mol. Biol. 218 (1991) 583. (d) J. Stubbe, J. Mol. Biol. Chem. 265 (1990) 5329. (e) A.C. Rosenzweig, C.A. Frederick, S.J. Lippard, P. Nordlund, Nature 366 (1993) 537. (f) R.G. Wilkins, Chem. Soc. Rev. (1992) 171.

[2] R.H. Holm, P. Kennepohl, E.I. Solomon, Chem. Rev. 96 (1996) 2239.

[3] (a) S. Ménage, B.A. Brenman, C. Juarez-Garcia, E. Munck, L. Que, Jr., J. Am. Chem. Soc. 112 (1990) 6423. (b) Y. Dong, S. Menage, B.A. Brenman, T.E. Elgren, H.G. Jang, L.L. Pearc, L. Que, Jr., J. Am. Chem. Soc. 115 (1993) 1851. (c) Y. Zang, T.E. Elgren, Y. Dong, L. Que, Jr., J. Am. Chem. Soc. 115 (1993) 811.

[4] Y. Nashida, K. Yamada, J. Chem. Soc., Dalton Trans. (1990) 3639.

[5] M. Tachibana, K. Sasaki, A. Ueda, M. Sakai, Y. Sakakibara, A. Ohno, T. Okamoto, Chem. Lett. (1991) 993. 
[6] (a) N. Kitajima, H. Fukui, Y. Moro-oka, J. Chem. Soc., Chem. Commun. (1988) 485. (b) N. Kitajima, M. Ito, H. Fukui, Y. Moro-oka, J. Chem. Soc., Chem. Commun. (1991) 102. (c) R.H. Fish, M.S. Konings, K.J. Oberhausen, R.H. Fong, W.M. Yu, G. Christou, J.B. Vincent, D.K. Coggin, R.M. Buchanan, Inorg. Chem. 30 (1991) 3002. (d) M. Fontecave, B. Roy, C. Lambeaux, J. Chem. Soc., Chem. Commun. (1991) 939. (e) I. Tabushi, T. Nakajima, K. Seto, Tetrahedron Lett. 21 (1980) 2565.

[7] (a) R.A. Leising, J. Kim, M.A. Pérez, L. Que, Jr., J. Am. Chem. Soc. 115 (1993) 9524. (b) S. Menage, J.M. Vincent, C. Lambeaux, G. Chottard, A. Grand, M. Fontecave, Inorg. Chem. 32 (1993) 4766.

[8] (a) B.P. Murch, F.C. Bradley, L. Que, Jr., J. Am. Chem. Soc. 108 (1986) 5027. (b) S. Ménage, J.M. Vincent, C. Lambeaux, M. Fontecave, J. Chem. Soc., Dalton Trans. (1994) 2081. (c) S. Ménage, E.C. Wilkinson, L. Que, Jr., M. Fontecave, Angew. Chem., Int. Ed. Engl. 34 (1995) 203. (d) R.A. Leising, R.E. Norman, L. Que, Jr. Inorg. Chem. 29 (1990) 2553. (e) D.H.R. Barton, A.H. Beck, D.K. Taylor, Tetrahedron 51 (1995) 5245. (f) Y. Dong, L. Que, Jr., K. Kaufmann, E. Münck, J. Am. Chem. Soc. 117 (1995) 11377. (g) R.P. Houghton, R. Rice, J. Chem. Soc., Chem. Commun. (1995) 2265. (h) J. Kim, E. Larka, E.C. Wilkinson, L. Que, Jr., Angew. Chem., Int. Ed. Engl. 34 (1995) 2048. (i) G. Bartoli, E. Marcanroni, M. Petrini, L. Sambri, Tetrahedron Lett. 35 (1994) 8453. (j) S. Zhang, K.S. Snyder, R.E. Sheperd, Inorg. Chim. Acta 201 (1992) 203.

[9] M. Lubben, Model Systems for Iron and Copper Containing Oxygenases, Ph.D. Thesis, University of Groningen, the Netherlands, 1994.

[10] (a) M.P. Hogerheide, J.T.B.H. Jastrzebski, J. Boersma, W.J.J. Smeets, A.L. Spek, G. van Koten, Inorg. Chem. 33 (1994) 4431. (b) M.P. Hogerheide, M. Wesseling, J.T.B.H. Jastrzebski, J. Boersma, H. Kooijman, A.L. Spek, G. van Koten, Organometalics (1995) 4483. (c) M.P. Hogerheide, S.N. Ringelberg,
J.T.B.H. Jastrzebski, J. Boersma, W.J.J. Smeets, A.L. Spek, G. van Koten, Inorg. Chem. 35 (1996) 1185. (d) M.P. Hogerheide, S.N. Ringelberg, M.D. Janssen, J. Boersma, A.L. Spek, G. van Koten, Inorg. Chem. 35 (1996) 1195.

[11] Y. Gultneh, A. Farooq, S. Liu, K.D. Karlin, J. Zubieta, Inorg. Chem. 31 (1992) 3607.

[12] S. Teipel, K. Griesar, W. Haase, B. Krebs, Inorg. Chem. 33 (1994) 456.

[13] E. Wehman, G. van Koten, D.M. Knotter, C.J.M. Erkamp, A.N.S. Mali, C.H. Stam, Recl. Trav. Chim. Pays-Bas 106 (1987) 370.

[14] R.A. Bartlett, J.J. Ellison, P.P. Power, S.C. Shoner, Inorg. Chem. 30 (1991) 2888.

[15] B. Cetinkaya, L. Gumrukcu, M.F. Lappert, J.L. Atwood, R. Shakir, J. Am. Chem. Soc. 102 (1980) 2086.

[16] K.F. Tesh, T.P. Hanusa, J. Chem. Soc., Chem. Commun. (1991) 879.

[17] P.A. van der Schaaf, J.T.B.H. Jastrzebski, M.P. Hogerheide, W.J.J. Smeets, A.L. Spek, J. Boersma, G. van Koten, Inorg. Chem. 32 (1993) 4111.

[18] (a) R.E. Norman, S. Yan, L. Que, Jr., G. Backes, J. Ling, J. Sanders-Loehr, J.H. Zhang, C.J. O'Connor, J. Am. Chem. Soc. 112 (1990) 1554. (b) S. Ménage, L. Que, Jr., New J. Chem. 15 (1991) 431.

[19] M. Aresta, C. Nobile, D. Petruzelli, Inorg. Chem. 16 (1977) 1817.

[20] A.L. Spek, Acta Crystallogr., Sect. A 46 (1990) C34.

[21] G.M. Sheldrick, SHELXs86, Program for crystal structure determination, University of Göttingen, Germany, 1986.

[22] G.M. Sheldrick, SHELXL93, Program for crystal structure determination, University of Göttingen, Germany, 1993.

[23] A.J.C. Wilson (Ed.), International Tables for Crystallography, vol. C, Kluwer, Dordrecht, The Netherlands, 1992. 